\title{
NEW WAYS IN THE COGNITIVE DIMENSION OF INFORMATION OPERATIONS
}

\author{
Zsolt HAIG \\ National University of Public Service, Budapest, Hungary \\ haig.zsolt@uni-nke.hu \\ Veronika HAJDU \\ National University of Public Service, Budapest, Hungary \\ hajdu.veronika@uni-nke.hu
}

\begin{abstract}
In this paper the authors introduce the cognitive dimension that is becoming more and more important in the field of information operations with special regard to psychological operations (PSYOPS). The strengthening role of influencing skills and technological progress has created new avenues and opportunities in the military field. The paper seeks to point out the relationship between marketing and PSYOPS. In connection with this, the study intends to present a new approach to PSYOPS that can achieve the operational goals which set by the leader by applying guerrilla marketing tools and methods.
\end{abstract}

KEYWORDS: information operations, PSYOPS, target audience, guerrilla marketing

\section{Introduction}

The information and related activities, including the role and importance of information operations has intensified over the years, increasingly plays a central function in the military operations. The force multiplier role of information may create an opportunity to with minimal losses, but a higher efficiency set to be available by the commander goals.

The new kind of warfare methods and new challenges that arise during the command, control and execution of military operations require the change and transformation of the military mindset. New skills like informational capabilities have to be highly considered. This conclusion is further underscored by the changes in the theater of war, as well as the appreciation and the emergence of civil society's role in peace-support operations. In addition, military operations are now underway not only in physical space, but also in cyberspace, even it cuts across continents without direct physical presence.

We are experiencing a significant strengthening of the human dimension, namely the cognitive skills among the information activities of the changed environment. Its purpose is in line with the concept of commander to influence the target groups in order to change their attitudes to achieve the intended operational objectives. The aim of this study is to point out the ever-increasing role of cognitive skills in the field of information operations. 
Some new methods and principles of influence will be presented which are already approved in the civil sphere and can also be adapted during military operations.

\section{The Strengthening Role of the Cognitive Capabilities in Military Operations}

Nowadays, owing to the explosive development of information technology, we can witness the most important role of information in all areas of social life. All of this has an impact on the conduct of military operations. The use of modern military information systems and information in different ways can significantly influence the ultimate outcome of the operations compared to earlier times.

The operational environment of the wars of our times is significantly different from conventional state on state armed conflict. These altered military operations are labeled with numerous names, such as asymmetric, irregular, fourth generation, counterinsurgency or hybrid warfare. Examples of hybrid warfare include the clashes in the areas of Eastern Ukraine or the activities applied by and against the Islamic State.

According to Hoffman „Hybrid threats incorporate a full range of different modes of warfare including conventional capabilities, irregular tactics and formations, terrorist acts including indiscriminate violence and coercion, and criminal disorder. Hybrid Wars can be conducted by both states and a variety of non-state actors. These multi-modal activities can be conducted by separate units, or even by the same unit, but are generally operationally and tactically directed and coordinated within the main battlespace to achieve synergistic effects in the physical and psychological dimensions of conflict. The effects can be gained at all levels of war" (Hoffman, 2007, p. 8).

Based on this definition it can also be seen that the role of synergistic effects reached in the psychological (or otherwise cognitive) physical and informational dimensions of conflicts is appreciated in these operations. In hybrid operations, indirect methods are used instead of direct intervention, whose influence is one of the decisive elements and in which the cultural aspects play a significant role too.

With the emergence of hybrid warfare - as a fourth generation warfare - the borders blur between the belligerents. According to Clausewitz in the first three generations of war, the separation between the soldier, the citizen and the state was always characteristic. One of the key features of fourth generation warfare is that the border between soldiers and civilians disappears, and non-state actors appear as belligerent. Accordingly among the goals of fourth generation warfare winning public support is important and often gets a top priority.

According to Allen, although conflicts in the physical dimension can be triggered in the cognitive dimension, the ultimate conflict cannot be resolved in the physical space. While steps can be taken to reduce the violence, the choice to use violence must be addressed primarily in the cognitive dimension. All conflicts in the cognitive space need to be resolved in the cognitive space, because that is where the cause is located. Resulting activities, such as violence in the physical space are only symptoms of the cause, and treating the symptoms alone will not resolve the causes (Allen, 2007, p. 285). Therefore in the military operations of the information age the precondition for success is the execution of influencing operations not only required during armed conflict, but also before and after it. The theses of information operations were developed into a coherent theoretical and practical system among the various conflict theories related to information. The emergence of this concept has gone back more than 20 years 
ago and its focal points and capabilities have changed significantly in recent years.

The NATO newest information operations doctrine defines them as , a staff function to analyze, plan, assess and integrate information activities to create desired effects on the will, understanding and capability of adversaries, potential adversaries and NAC approved audiences in support of Alliance mission objectives" (AJP-3.10, 2015, p. I-5). They consist of three interrelated areas, such as:

- information activities focusing on preserving and protecting friendly forces' freedom of action in the information environment at all times;

- information activities focusing on behaviors, perceptions and attitudes of audiences;

- information activities focusing on countering an adversary's propaganda as well as their command and control (C2) functions and capabilities (AJP-3.10, 2015, p. I-5).

There are many information activities and capabilities in these three areas e.g. operation security, deception, electronic warfare, computer network operations psychological operations etc. They are realized in the physical, informational (or virtual) and cognitive dimensions.

The NATO information operations doctrine lists psychological operations (PSYOPS) as an information activity among others. Cognitive capabilities have played an important role in both world wars, but their full accomplishment is observed in today's military operations other than war. PSYOPS as a key capability of information operations, has become an increasingly important area over the years, including in operations such as "Enduring Freedom" in Afghanistan, where besides air operations, humanitarian operations had a role too. Furthermore during the "Iraqi Freedom" operation, while using the ammunition, leaflets were also dropped by urging the enemy soldiers to be surrendered. (Friedman)

According to the NATO PSYOPS doctrine, psychological operations are „planned activities using methods of communication and other means directed at approved audiences in order to influence perceptions, attitudes and behavior, affecting the achievement of political and military objectives" (AJP-3.10.1, 2014). This can be simple oral communication or any information transmitted accessible media device. While PSYOPS activities in war are aimed at deterring and intimidating the enemy, in today's peace-support operations the goal of PSYOPS is to influence and obtain the support of the neutral population.

The activities in the physical and informational dimensions are already aimed at influencing events in the cognitive dimension in many cases (Rózsa, 2017, p. 12). All of this is displayed both in the analysis of target group and environment, like in the Maslow pyramid for example. Thus, the essential element is the human actor, who is the main character of military psychological operations.

3. The Significance of the Information Environment in Psychological Operations and Marketing Activity

Information environment is the arena of information operations, in which information based activities are conducted in the physical-, informational- and cognitive dimensions.

The physical dimension is the dimension of real world, where physical activities occur and individuals, nations, cultures and societies interact (AJP-3.10, 2015 , p. I-2). The physical dimension includes: human beings; command and control facilities; paper based media; infocommunication technologies, like telecommunications assets, computers, laptops, smart phones, tablets, etc. In this dimension the information activities are 
realized across national, economic, and geographical boundaries (JP 3-13, 2014, p. I-2-I-6)

The informational dimension encompasses where electronic based information activities occur. In this dimension information is collected, processed, stored, disseminated, and protected. According to the new NATO Information operations doctrine, this dimension is called as virtual domain.

The cognitive dimension or according to the NATO doctrine, psychological domain encompasses the minds of individuals who transmit, receive, and respond to or act on information (AJP-3.10, 2015, p. I-2). This dimension is influenced by individual and cultural beliefs, norms, vulnerabilities, motivations, emotions, experiences, morals, education, mental health, identities, and ideologies. Defining these influencing factors in a given environment is critical for understanding how to best influence the mind of the target audiences and create the desired effects. According to the US Joint Information Operations doctrine, this dimension constitutes the most important component of the information environment (JP 3-13, 2014, p. I-3).

The cognitive dimension and the various cognitive capabilities that can be realized in it have a particular importance in today's military operations. The Military Information Support Operations - MISO doctrine designed to mitigate negative appreciation of PSYOPS in the US military. It emphasizes the importance of environmental and target group analysis in the cognitive dimension, complemented by competency and expertise of the commander (JP 3-13.2, 2010, p. 108).

The focus has been on developing culturally and environmentally sensitive messages, and the use of sophisticated media as a communication tool. This can give rise to a number of methods and approaches that are not common in military operations.

Figure no. 1 shows the processes involved in the three dimensions of the information environment, ultimately resulting fulfillment of influence capability. Information activities in the three dimensions are directly or indirectly aimed at target groups.

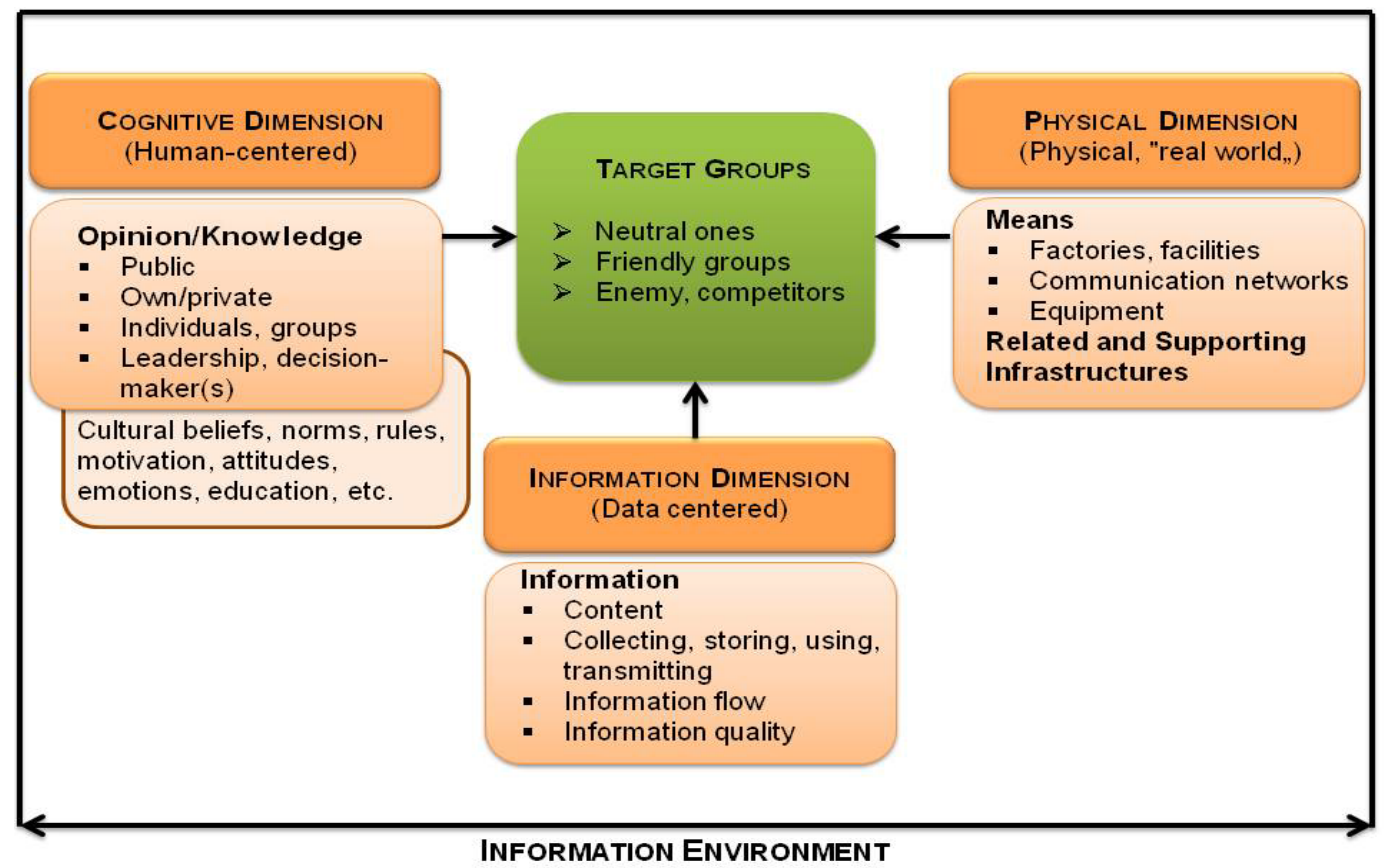

Figure no. 1: Representing the information environment dimensions Source: based on (JP 3-13, 2014, p. I-2-I-6), edited by the authors 
The tools and methods are all involved in all three dimensions. They have an impact on the ability of the target group to collect, process and analyze the information before making the decision.

\section{PSYOPS and Marketing Contexts}

PSYOPS is practically linked to marketing and marketing communication in the civil field, where the goal is to influence a certain target group through various devices, in accordance with management goals. Communicating with the target group, reaching them is achieved through different categories and themes both in PSYOPS and marketing. PSYOPS planners use marketing fundamentals and methods to create themes. In marketing, according to the macroeconomic approach "consumer behavior can influence economic process and trends" (Horváth, 2010, p. 11). In the light of this, various sociological researches have spread to reveal and to confine the various consumer behavior patterns. This delimitation can also be a huge advantage during military operations, as better knowledge of the target group can result in the build up a more successful argumentation.

In the 21st century there is a broad palette where both PSYOPS and marketing can move around, learning from each other even adapting each other's practices. Although not all marketing rules can be adapted to PSYOPS, but there are common features that can contribute to the implementation of both methods. In marketing well-planned, strategically thought-out plans are being developed, which defining target groups, positioning products, planning price wars, allocating resources, and taking losses.

There are also a number of methods used in civil practice through which cognitive abilities can prevail in military PSYOPS. Such an analytical method can be the analysis of the behavior of target group that was specified by Kotler (see Figure no. 2). These factors may help to determine which elements modify the opinion and cognitive dimension of the human factor. Thus, this method can be applied well in the planning process of PSYOPS activity. The importance of these factors is demonstrated by the fact that the Hungarian Defense Forces Civil-Military Cooperation and Psychological Operations Center has issued separated handbooks to support Afghanistan and Balkan missions. They detail local cultural characteristics, habits, infrastructure characteristics, population, economy information, the sights, or the legal system. (CIMIC Handbook, 2005, p. 63)
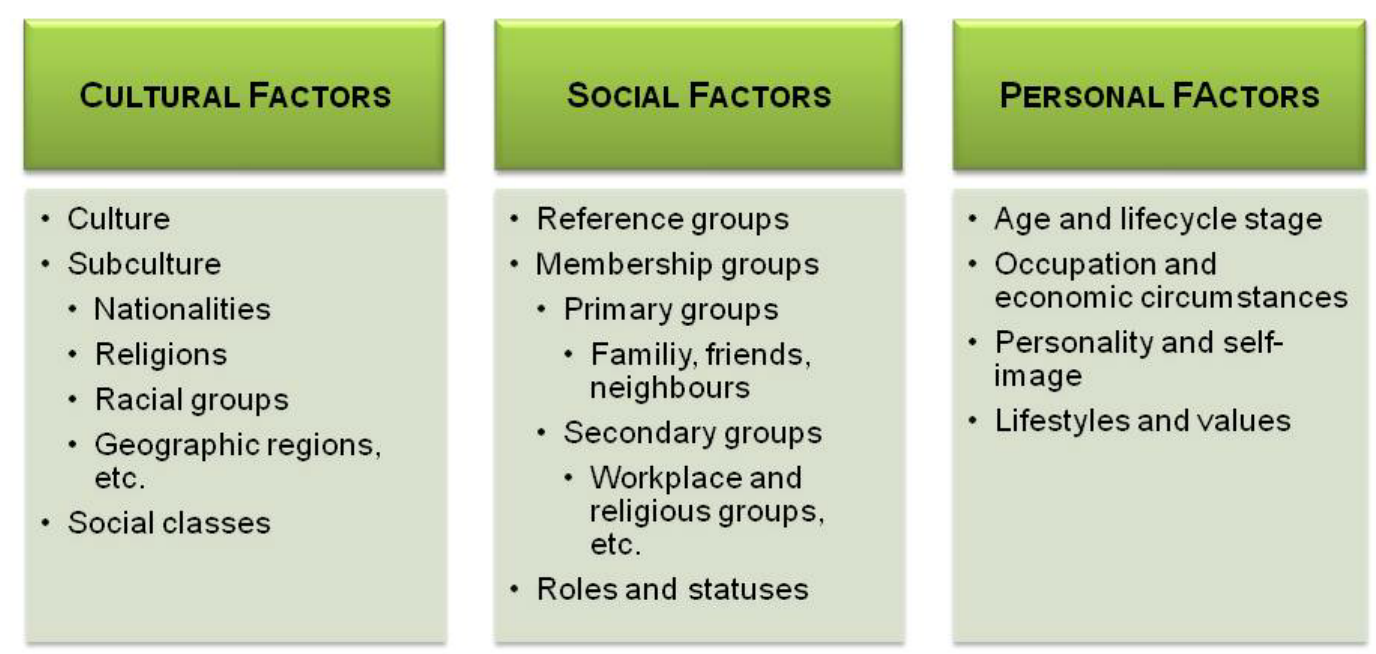

Figure no. 2: Influencing factors which determine the behavior of the target audiences Source: based on (Kotler, - Keller, 2008, pp. 246-258), edited by the authors 
We do not want to analyze the factors in detail since their importance is unquestionable both in military and civil fields. However it is significant, that during persuasion and influence, the focus should be placed on what important is to the target group, and why it is beneficial for him to change his behavior and attitude.

The development of networked infocommunication technologies has fundamentally changed the possibilities of interpersonal and mass communication. The actors can react to events in their actuality, immediately. This may even hinder the successful implementation of PSYOPS, as powerful distortion processes are created. Because of the distortions of the media, entertainment, recreation and education, information, and propaganda or influencing are often blurred (Castells, 2007, p. 19).

\section{Using Non-Conventional Method to Influence the Cognitive Dimension Through Marketing Approach}

The strength of non-conventional methods lies in the fact that they use nonstandard methods to influence human consciousness. As a result of this change of attitude, the influenced party will re-evaluate its entire cognitive decision-making process. The collection, processing, use and transmission of information are done in a variety of ways and methods. From the definition of guerrilla war, a marketing direction has emerged that attempts to accomplish its goals using atypical tactics of its name. The main advantage of guerrilla marketing is an idea-based communication method in which it draws attention to extraordinary solutions. It is characterized by continuous innovations, unusual, new and surprising methods for transmitting messages. Its foundation is mostly rumor, through which the message can be accessed to anyone, as through the various social groups - family, friends, staff, members of religious communities wide masses can also be reached. Folk, communal, local support is one of their most important weapons, which can provide moral, personal and financial support, and last but not least, it can also lead to successful implementation of PSYOPS (Forgács, 2009, p. 91). Therefore, the importance of guerrilla marketing is that it maintains a close relationship with the target group and knows its motivations.

There are many varieties of guerrilla marketing that serve both online and offline ways to achieve the set goals such as for example, aims to attain attitude change of the target group in accordance with the PSYOPS goals. Table no. 3 shows a number of types of guerrilla marketing, however, due to the extent limitations; only a few types are described below.

From perspective of PSYOPS, the most important types of guerrilla marketing are the followings (Guerrillaonline.com):

- Viral Marketing: Word of Mouth advertising, which is spread over the Internet, on mobile communication devices, or through face-to-face communication. It can be described as an epidemic communication process. Once it is "unleashed", it becomes unmanageable for the message to reach. Unfortunately, today it has become a "favorite" method of terrorists with the use of twitter, YouTube.

- Undercover Marketing: The product is presented to target audience in a way that does not appear to be commercial; marketing pressure does not apply. Today, blogs, forums, and video sharing sites typically give positive opinions to people who are involved in the product. It generates low budget and positive rumors.

- Tissue-packing Advertising: The advertisement is placed on tissue-papers, and since it is very useful product for people, they preserve for using. The products are not limited only on tissues, however the campaign often depends highly on cost of the products and value for their target audience. This method can also be known for PSYOPS. During the World 
Wars, in propaganda activities were also a popular way to send messages via products.

- Ambient Marketing: "Medium is the message" (McCluhan, 1964, p. 8). Ambient media means the surrounding nontraditional advertising environment, which affects the target audience in their own environment in an unexpected way and shape. The ambient media reflects its direct environment, creates a special atmosphere, and if this atmosphere has a valuable and relevant content for the target audience, it will receive the message and will not reject the advertisement or the message.

- Ambush Marketing: A marketing technique where advertisers strive to link their product to a particular event in the eyes of potential target audience without paying sponsorship for the event. An example of this is when the local radio transmits their messages to allied soldiers in the eyes of the general public, creating the appearance of supporting by the channel and the leaders of the country.

It is important to note that the types shown above follow a certain division, and of course there are different classifications.

Different guerrilla marketing methods can otherwise aid the execution of PSYOPS and their goals. There are several common points for defining each type of model that can reinforce or weaken the efficiency of the method, either in military or civilian applications. These features are:

- unexpected: The message is displayed at a moment when the target group is not counting on it at all.

- drastic: It tries to influence the target audience in an uncommon way and to achieve attitudinal change.

- wide reach: The messages are transmitted between each other, reach high speeds from one person to the next, based on a trusted relationship, even reaching groups that are difficult to access.

- cheap: The cost has to be paid just once in the beginning. The communication channel is essentially the interrelationship between people. Then everything goes by itself.

- one-shot: The message can be seen only once in an appropriate way,-then it loses the power of surprise and unexpectedness, and after that it only builds on the power of the rumor.

- target audience (TA) benefit/ goodwill: The guerrilla marketing campaign must provide something that benefits the target audience. For example, in the case of PSYOPS, it could be satisfaction, acceptance, support, trust, etc.

Table no. 1 summarizes the most important aspects, characteristics for each guerrilla marketing method that can contribute to the PSYOPS goals.

Table no. 1 Types of guerrilla marketing and their applicability in PSYOPS Source: based on (Guerrillaonline.com), edited by the authors

\begin{tabular}{|c|c|c|c|c|c|c|c|}
\hline \multicolumn{8}{|c|}{ Using in PSYOPS } \\
\hline $\begin{array}{l}\text { Guerilla Marketing } \\
\text { Methods }\end{array}$ & Unexpected & Drastic & One-shot & Cheap & $\begin{array}{l}\text { TAbenefit/ } \\
\text { Goodwill }\end{array}$ & $\begin{array}{l}\text { Wide } \\
\text { reach }\end{array}$ & $\begin{array}{c}\text { Operation } \\
\text { risk }\end{array}$ \\
\hline Astroturfing & * & * & * & * & * & * & high \\
\hline Viral Marketing & $* * *$ & $* * *$ & * & ** & $* *$ & $* * *$ & medium \\
\hline Undercover Marketing & * & * & $* *$ & $* * *$ & $* * *$ & * & high \\
\hline Wild Posting & * & * & $* * *$ & $* * *$ & * & $* *$ & low \\
\hline $\begin{array}{l}\text { Tissue-packing } \\
\text { Advertising }\end{array}$ & $* *$ & * & $* * *$ & $* * *$ & $* * *$ & $* *$ & low \\
\hline
\end{tabular}




\begin{tabular}{|c|c|c|c|c|c|c|c|}
\hline \multicolumn{8}{|c|}{ Using in PSYOPS } \\
\hline $\begin{array}{l}\text { Guerilla Marketing } \\
\text { Methods }\end{array}$ & Unexpected & Drastic & One-shot & Cheap & $\begin{array}{l}\text { TAbenefit/ } \\
\text { Goodwill }\end{array}$ & $\begin{array}{l}\text { Wide } \\
\text { reach }\end{array}$ & $\begin{array}{c}\text { Operation } \\
\text { risk }\end{array}$ \\
\hline Ambient Marketing & $* * *$ & $* *$ & $* * *$ & ** & ** & ** & medium \\
\hline Presence Marketing & $* * *$ & $* * *$ & $* * *$ & $* * *$ & $* * *$ & ** & low \\
\hline Alternative Marketing & $* *$ & ** & $* *$ & $* *$ & $* *$ & $* *$ & medium \\
\hline Experiential Marketing & $* * *$ & * & $* * *$ & $* * *$ & $* * *$ & $* * *$ & low \\
\hline Presume Marketing & * & * & $* *$ & $* * *$ & $* *$ & * & low \\
\hline Ambush Marketing & $* * *$ & ** & $* * *$ & $* * * *$ & $* *$ & $* *$ & medium \\
\hline
\end{tabular}

* : very difficult to adapt

**: can be adapt without problem

${ }^{* * *}$ : easy to adapt

The table also shows the degree of each marketing method characteristics that may be present in the PSYOPS application. Of course, military use can somewhat restrict the possibility of using certain types of guerrilla marketing (lack of internet, cultural features, religious differences, rules, etc.), but its impact and influence can be greatly enhanced by a thorough target group and environmental analysis.

The use of the methods listed in the table also involves a certain degree of operational risk (low, medium, high), which is important to consider during planning, as it may even cause the opposite effect of the objectives set.

\section{Conclusions}

To be effective current events require to have up-to-date and accurate information be available for us. The use of information operations in history has many documented examples, like deception or PSYOPS. At the same time as the development of digital technology, commanders can apply new methods of non-kinetic influencing, especially in the field of virtual space and human influence. In the changing operational environment, new methods are needed to achieve a more successful implementation of PSYOPS goals. Unfortunately, these new methods are also available on the opponent's side.
In this study PSYOPS were approached from a non-traditional marketing method, the guerrilla marketing point of view, whose tools and methods could make it possible to help achieve PSYOPS goals. The importance of guerrilla marketing is due to the variety of methods, which strive to achieve change of attitudes, through the possibilities offered by technology and creativity. By building on the "power" of the message and the activity of the target audience, it tries to reach as many people as possible. As an intermediary medium, people become the communication channel, giving credibility to the content of the message, as information comes from a friend, acquaintance, and opinion leader, facilitating the acceptance of the content of PSYOPS messages as well.

In our opinion, and based on the research so far, from the perspective of PSYOPS it is worth considering and following marketing activities in the civil sphere that are constantly evolving and applying the latest methods and tools for success. Adaptive application of them offers new opportunities for PSYOPS, which can increase the efficiency of operations. In addition, marketing research as a separate discipline conducts a continuous and wide-ranging sociological, demographic, technological, psychological 
researches that can be applied to military PSYOPS.

Marketing and PSYOPS are quite a different area, but the basic processes and goals (target group, attitude change) are similar. As a part of marketing, marketing research and marketing communication (advertising) involve a methodology that can help increase PSYOPS efficiency. Therefore developing a PSYOPS marketing strategy is advisable, which could be determined by the fundamentals of marketing research.

\section{REFERENCES}

AJP-3.10 (2015). Allied Joint Doctrine for Information Operations.

AJP-3.10.1 (2014). Allied Joint Doctrine For Psychological Operations. Edition B Version.

Allen, P.D. (2007). Information Operations Planning. Boston: Artech House.

Castells, M. (2007): A hálózati társadalom kialakulása. 11-28. In: Halácsy, P. et. al.: Új Média RE:Mix 1. - Hatalom a mobiltömegek kezében, Budapest: Typotex Elektronikus Kft.

CIMIC Handbook (2005). CIMIC Handbook of the Balkans - Bosnia Herzegovina, Macedonia, Kosovo. Budapest: Authors.

Forgács, B. (2009). Napjaink hadikultúrái (A hadviselés elmélete és fejlödési tendenciái a modern korban). (PhD dissertation).

Friedman, H.A. (2017) Operation Iraqi Freedom, available at: http://www.psywarrior.com/OpnIraqiFreedomcont2.html.

Guerrillaonline.com. (2017). Types of guerrilla marketing, available at: http://www.guerrillaonline.com/cs/Guerrilla-Marketing-types-65.htm.

Hoffman, F.G. (2007). Conflict in the 21st century: The rise of Hybrid Wars. Arlington, Virginia: Potomac Institute for Policy Studies, available at: http://www.potomacinstitute.org/ images/stories/publications/potomac hybridwar_0108.pdf.

Horváth, Á. (2010). Fogyasztói magatartás. Gödöllő: Szent István Egyetem.

JP 3-13 (2014). Information operations, available at: http://www.dtic.mil/doctrine/ new pubs/jp3_13.pdf.

JP 3-13.2 (2010). Military Information Support Operations, available at: https://info.publicintelligence.net/JCS-MISO.pdf.

Kotler, P. - Keller, K. L. (2008). Marketingmenedzsment. Budapest: Akadémia Kiadó. Books.

McCluhan, M. (1964). Understanding media: The extensions of man. London: Signet

Rózsa, T. (2017). Az információs müveletek vizsgálata, különös tekintettel a befolyásolási képességek alkalmazásának lehetőségeire a Magyar Honvédség feladatrendszerében. (PhD dissertation). 